\title{
30. ORGANIC MATTER IN SEDIMENTS OF SITE 808, NANKAI ACCRETIONARY PRISM, JAPAN ${ }^{1}$
}

\author{
U. Berner ${ }^{2}$ and J. Koch ${ }^{2}$
}

\begin{abstract}
Microscopic studies reveal a predominance of terrestrial organic matter in sediments of Site 808. Terrestrial vitrinite and inertinite are more abundant ( $73 \%$ to $100 \%$ ) than marine organic matter (alginite, $0 \%$ to $27 \%$ ), which increases from open oceanic deposits of the Shikoku Basin sediments to sediments of the outer trench wedge. The abundance of terrestrial organic matter is also reflected through carbon isotope values of $-23 \%$ to $-25.9 \%$. Mass accumulation rates of organic carbon are low in hemipelagic sediments of the Shikoku Basin $\left(<0.2 \mathrm{~g} / \mathrm{cm}^{2} / \mathrm{k} . \mathrm{y}\right.$.) but increase significantly in sediments of the Nankai Trench $(0.2$ to $1.7 \mathrm{~g} / \mathrm{cm}^{2} / \mathrm{k} . \mathrm{y}$.). Although the organic mass accumulation is high in sediments of the Nankai Trench, a comparison of sedimentation rates and total organic carbon suggests relative dilution of organic carbon through turbidite flows. Calculated marine paleoproductivity of organic carbon is low in sediments of the open ocean (Shikoku Basin) and increases closer to the shore (Nankai Trench). Thermal evolution of organic matter is obtained from vitrinite reflectance measurements. Two populations of vitrinites have been observed between 600 and $1234 \mathrm{mbsf}$. Reflectance values change with increasing depth and temperature in both groups of vitrinite $(0.3 \%$ to $0.68 \%$ in group $1 ; 0.6 \%$ to $1 \%$ in group 2$)$.
\end{abstract}

\section{INTRODUCTION}

During Ocean Drilling Program (ODP) Leg 131, Site 808 was drilled on the Nankai accretionary prism (Fig. 1), penetrating $1280 \mathrm{~m}$ of turbiditic and hemipelagic sediments overlying the basaltic basement (Taira, Hill, Firth, et al., 1991). Organic petrological and geochemical studies provide information on the amount, type, and thermal alteration of organic matter. This paper gives an overview of the accumulation and alteration of organic matter in sedimentary environments of Site 808 .

\section{SAMPLES AND METHODS}

A total of 147 sediment samples were collected from Site 808 in $10-\mathrm{m}$ intervals over a depth range from 3 to $1280 \mathrm{mbsf}$.

Total organic carbon (TOC) was calculated from total sediment carbon (measured by combustion of sediments with a NA 1500 Carlo Erba NCS analyzer) and carbonate carbon (using a Coulometrics 5011 coulometer). The data and methods are given in Taira, Hill, Firth, et al. (1991). Mass accumulation rates (MARCorg) of organic carbon were calculated from the equation of Bordovskiy (1965):

$$
M A R_{\text {Corg }}=\frac{T O C}{100} \cdot S R \cdot D B D
$$

where $S R$ is the sedimentation rate (cm/k.y.) and $D B D$ is the dry-bulk density $\left(\mathrm{g} / \mathrm{cm}^{3}\right)$. We were not able to measure the DBD of samples discussed in the paper. We instead approximated the data given in Table 1 through measured DBD data of adjacent samples of the same lithology which are given in Taira, Hill, Firth, et al. (1991). The SR data have been taken from Taira, Hill, Firth, et al. (1991).

Paleoproductivity (PP) of surface waters was estimated using the empirical equation of Stein (1986):

$$
P P=5.31 \cdot(C \cdot D B D)^{0.71} \cdot S R^{0.07} \cdot D E P^{0.45}
$$

where $C$ is marine organic carbon (wt\%) and DEP is the paleowater depth in meters. Data on TOC, $\mathrm{MAR}_{\text {Corg, }}$, and PP are given in Table 1.

\footnotetext{
' Hill, I.A., Taira, A., Firth, J.V., et al., 1993. Proc. ODP, Sci. Results, 131: College Station, TX (Ocean Drilling Program).

${ }^{2}$ Bundesanstalt für Geowissenschaften und Rohstoffe, Stilleweg 2, D-3000 Hannover 51, Federal Republic of Germany.
}

Kerogen microscopic analyses of selected samples were conducted after kerogen concentration and removal of carbonates and silicates by treating the samples with HCL and HF. The dried material was embedded in resin. Maceral analyses were performed on polished blocks in reflected and fluorescence light (blue-light excitation, magnification 500x). Vitrinite reflectance was measured in oil immersion $(\lambda=546 \mathrm{~nm})$. Due to the high amount of clay particles in the samples we were not able to identify amorphous liptinite. We therefore report only particulate liptinite, which in this case is identical to alginite. The data on relative amounts of alginite, vitrinite, and inertinite are compiled in Table 2.

Kerogens were prepared for carbon isotope analyses using methods described in Schoell (1984). Carbon isotope ratios were measured relative to the Pee Dee Belemnite (PDB) standard with a Finnigan MAT 251 mass spectrometer. Values are reported in Table 1 as:

$$
\delta^{13} C_{\text {sample }}=\left[\frac{{ }^{13} C / 12 C_{\text {sample }}}{{ }^{13} C /{ }^{12} C_{\text {standard }}}-1\right] \cdot 1000 \%
$$

\section{RESULTS AND DISCUSSION}

\section{Hemipelagic Sediments of the Shikoku Basin}

Hemipelagic muds were recovered at Site 808 between 1243 and 618 mbsf. They represent sediments of the Shikoku Basin (Taira, Hill, Firth, et al., 1991). The lower section (1243 to $824 \mathrm{mbsf}$ ) was deposited distal to the Nankai Trench whereas the upper section represents sedimentation closer to the trench. The sedimentation rates were low and ranged from 6.5 to $214.3 \mathrm{~m} / \mathrm{m}$.y. (Taira, Hill, Firth, et al., 1991). The amount of TOC increases from $0.04 \%$ to $0.8 \%$ with decreasing age (13.6 to 0.46 m.y.) and coincides with an increase of the mass accumulation rate of organic carbon from 0.0003 to $0.2 \mathrm{~g}$ carbon per $\mathrm{cm}^{2}$ per $1000 \mathrm{yr}$ from bottom to top (Fig. 2, Table 1). The amounts of TOC in the lower Shikoku Basin sediments of Site 808 are comparable (Fig. 3) to those observed under similar hemipelagic conditions (Müller and Suess, 1979; Stein et al,, 1989). With increasing sedimentation rates an increase of the TOC values is observed (Fig. 3).

Interestingly, the organic matter of these oceanic sediments consists predominantly of terrestrially derived vitrinites and inertinite (Fig. 4, Table 2). Only $0 \%$ to $9 \%$ of the macerals consist of alginite of presumably marine origin. This suggests that $91 \%$ to $100 \%$ of the organic components are allochthonous. The terrestrial organic matter could have been transported into the ocean via riverine inputs and 


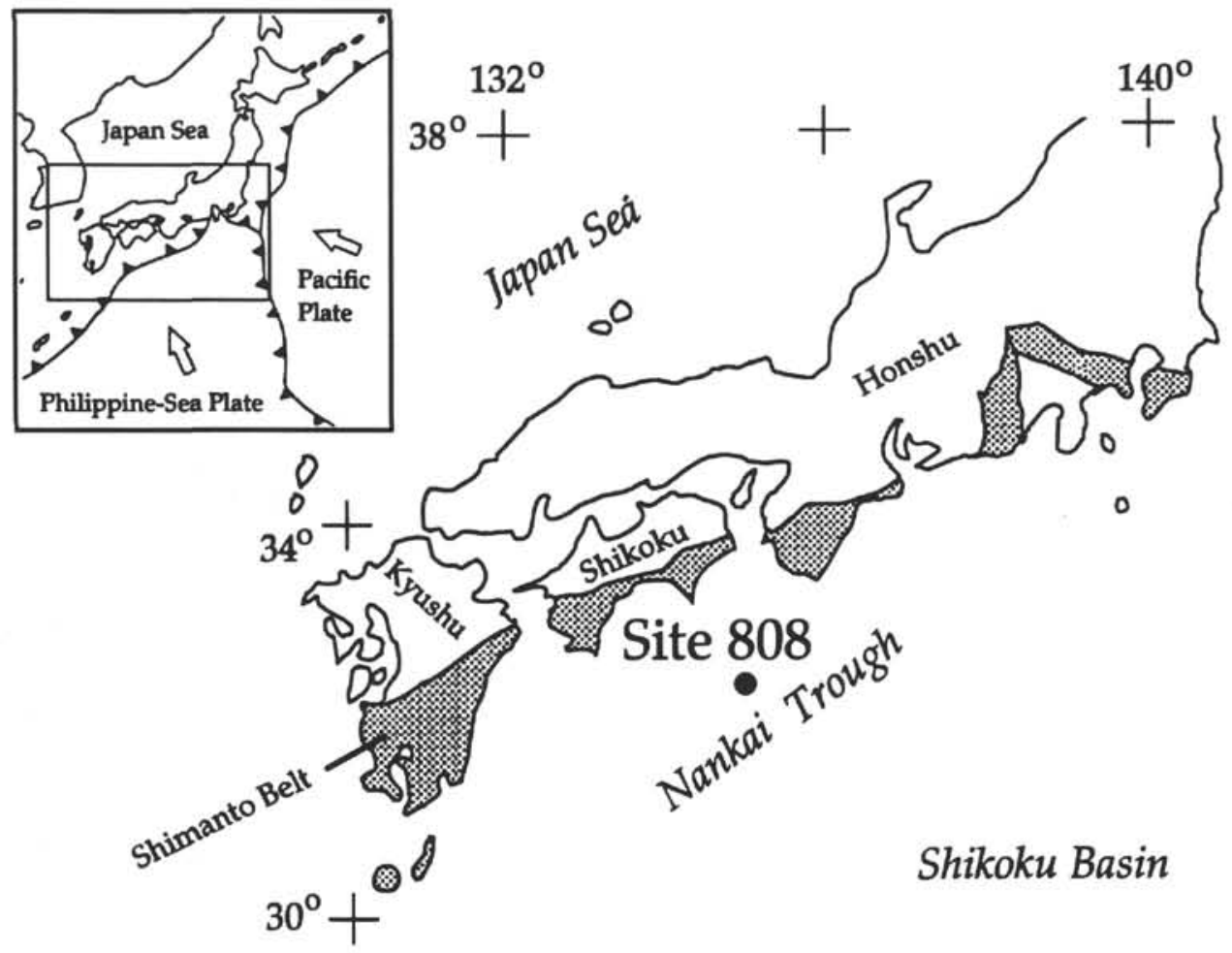

Figure 1. Location of Site 808 on the Nankai accretionary prism.

shifted laterally into distal oceanic areas by marine currents. The other possible transportation medium for terrigenous particles could have been aeolian dusts, which, according to Zafiriou et al. (1985), could account for at least $50 \%$ of the terrigenous organic matter preserved in deep-ocean sediments. The atmospherically introduced organic matter is largely refractory (Zafiriou et al., 1985). The inertinitic component of the Shikoku Basin sediments which makes up approximately $60 \%$ of the organic matter could partly be explained as aeolian input. But also long-distance transportation and subsequent (microbial) degradation of terrestrial organic matter in the ocean could lead to formation of inertinite (Prahl, 1985; Prahl and Muehlhausen, 1989). The occurrence of at least two vitrinite populations of different reflectivities (Fig. 5, Table 2) in the Shikoku Basin sediments could also be related to different input sources of terrestrial organic matter.

The predominance of terrigenous components over marine organic matter could be due to a higher stability of the terrestrial organic material. This can be explained by the high aromaticity of these organic particles, whereas marine organic matter consists largely of long-chain molecules that can be degraded easily (Tissot and Welte, 1984). Consequently, only a small portion of the primary organic carbon produced by oceanic plankton will be preserved in sediments of the open ocean. But, based on empirical observations, it is still possible to estimate from equation 3 the paleocarbon production of ocean waters (Stein, 1986). If we assume that the observed alginite is of marine planktonic origin, then approximately $2 \%$ of the TOC is of marine origin in the lower Shikoku Basin sediments (average value from alginite content). Based on this assumption, the paleocarbon productivity would have been $5 \mathrm{~g}$ carbon per $\mathrm{cm}^{2}$ per $\mathrm{yr}$ (Fig. 2). It is higher ( 10 to $20 \mathrm{~g}$ carbon per $\mathrm{cm}^{2}$ per $\mathrm{yr}$ ) in the upper Shikoku Basin sediments, where on average $7 \%$ of TOC is related to marine plankton (Fig. 4, Table 2). The paleoproductivity values related to hemipelagic sediments of Site 808 are similar to those from open oceans reported by Romankevich (1984). The increase in paleoproductivity in the upper Shikoku sediments could be due to a higher nutrient supply closer to the coast.
Carbon isotope data of kerogens from the Shikoku Basin sediments show little variation with average values around $-24 \%$ (Fig. 4 , Table 3). Tertiary kerogens of terrestrial origin have a carbon isotope range from $-24 \%$ to $-29 \%$ and modern land plants of the C-3 photosynthetic cycle range from $-24 \%$ to $-32 \%$, whereas marine plankton varies between $-18 \%$ and $-22 \%$ (Schoell, 1984, and literature cited therein). From the carbon isotope ratios it is likely that the Shikoku Basin kerogens contain a higher portion of terrestrial organic matter, as the average kerogen value of $-24 \%$ is similar to higher land plant values and deviates from those of marine plankton. The $\delta^{13} \mathrm{C}$ values increase slightly from $-24.7 \%$ to $-23.3 \%$ from base to top. Although this increase in $\delta^{13} \mathrm{C}$ is accompanied by an increase of marine liptinite (Fig. 4, Table 2), it is not possible to relate this isotope shift to linear mixing between terrestrial and marine organic matter, as proposed by Hedges and Mann (1979). The observed increase of approximately 5\% marine organic matter in the Shikoku Basin sediments can only account for an isotope shift of $0.2 \%$ if we assume constant isotopic compositions for both marine and terrestrial organic matter. It is therefore likely that during the period of more than 13 m.y., isotope variations must have occurred in both types of organic matter. The decrease of inertinite relative to vitrinite from lower to upper Shikoku Basin sediments (Fig. 4) already suggests a change of the source for the organic matter. This also makes it likely that slight isotope variations could occur in the terrestrial portion of the kerogen. Changes of water temperature could lead to changes in the planktonic communities that in turn could lead to variations of the carbon isotope ratios of the marine organic matter (Sackett et al., 1966).

\section{Sediments of the Nankai Trench and Wedge}

Sediments recovered between 618 and 0 mbsf were deposited in the Nankai Trench proximal to the accretionary prism and on the wedge itself (Taira, Hill, Firth, et al., 1991). They consist of hemipelagic muds and turbidite flows. Sedimentation rates range from 214 to $1381 \mathrm{~m} / \mathrm{m}$.y. (Taira, Hill, Firth, et al., 1991). TOC varies from $0.4 \%$ 
Table 1. Total organic carbon, mass accumulation rates (MAR), paleoproductivity, and carbon isotope ratios of kerogens from Site 808.

\begin{tabular}{|c|c|c|c|c|c|c|c|c|c|c|c|}
\hline $\begin{array}{l}\text { Core, section, } \\
\text { interval }(\mathrm{cm})\end{array}$ & $\begin{array}{l}\text { Depth } \\
\text { (mbsf) }\end{array}$ & $\begin{array}{l}\text { TOC } \\
(\%)\end{array}$ & $\begin{array}{c}\text { MAR } \\
\left(\mathrm{g} / \mathrm{cm}^{2} / \mathrm{k} . \mathrm{y} .\right)\end{array}$ & $\begin{array}{l}\text { Paleoproductivity } \\
\left(\mathrm{g} / \mathrm{cm}^{2} / \mathrm{yr}\right)\end{array}$ & $\begin{array}{l}\delta^{13} \mathrm{C} \\
(\% \infty)\end{array}$ & $\begin{array}{l}\text { Core, section, } \\
\text { interval }(\mathrm{cm})\end{array}$ & $\begin{array}{l}\text { Depth } \\
\text { (mbsf) }\end{array}$ & $\begin{array}{l}\text { TOC } \\
(\%)\end{array}$ & $\begin{array}{c}\text { MAR } \\
\left(\mathrm{g} / \mathrm{cm}^{2} / \mathrm{k} \cdot \mathrm{y} .\right)\end{array}$ & $\begin{array}{l}\text { Paleoproductivity } \\
\qquad\left(\mathrm{g} / \mathrm{cm}^{2} / \mathrm{yr}\right)\end{array}$ & $\begin{array}{l}\delta^{13} \mathrm{C} \\
(\%)\end{array}$ \\
\hline \multirow[t]{2}{*}{$131-808 \mathrm{~A}-$} & & & & & & $37 \mathrm{R}-1,0-1$ & 645.50 & 0.30 & 0.0583 & 9.3 & - \\
\hline & & & & & & $38 R-5,0-1$ & 660.90 & 0.45 & 0.1092 & 13.2 & -23.5 \\
\hline $1 \mathrm{H}-2,145-150$ & 2.95 & 0.58 & 0.5649 & - & -24.0 & $39 \mathrm{R}-4,0-2$ & 669.00 & 0.78 & 0.1893 & 19.7 & - \\
\hline $2 \mathrm{H}-6,0-5$ & 13.80 & 0.66 & 0.6429 & - & - & $40 \mathrm{R}-1,0-2$ & 674.20 & 0.63 & 0.1529 & 17.0 & - \\
\hline $3 \mathrm{H}-6,0-5$ & 23.30 & 0.73 & 0.7110 & - & - & $41 \mathrm{R}-1,148-150$ & 685.28 & 0.70 & 0.2430 & 18.4 & - \\
\hline $4 \mathrm{H}-2,0-5$ & 26.80 & 0.63 & 0.6136 & - & - & $42 R-1,0-2$ & 693.50 & 0.42 & 0.1458 & 12.9 & - \\
\hline $5 \mathrm{H}-6,130-134$ & 43.60 & 0.66 & 0.6429 & - & - & $43 R-1,0-3$ & 703.20 & 0.89 & 0.1753 & 21.2 & - \\
\hline $6 \mathrm{H}-1,0-5$ & 44.30 & 0.34 & 0.3312 & - & - & $44 \mathrm{R}-5,0-1$ & 718.40 & 0.43 & 0.0847 & 12.8 & -23.5 \\
\hline $7 \mathrm{H}-2,5-10$ & 55.35 & 0.62 & 0.6039 & - & - & $45 \mathrm{R}-1,0-2$ & 722.00 & 0.62 & 0.1221 & 16.6 & - \\
\hline $8 \mathrm{H}-1,133-135$ & 64.63 & 0.52 & 0.5065 & - & - & $46 \mathrm{R}-1,0-3$ & 731.70 & 0.50 & 0.0985 & 14.3 & - \\
\hline $9 \mathrm{H}-4,0-5$ & 72.80 & 0.63 & 0.6136 & - & - & $47 \mathrm{R}-1,0-2$ & 741.40 & 0.48 & 0.0946 & 14.0 & - \\
\hline $10 \mathrm{H}-5,0-5$ & 83.90 & 0.13 & 0.1473 & - & - & $48 \mathrm{R}-3,123-125$ & 755.33 & 0.43 & 0.0867 & 13.3 & -22.9 \\
\hline \multirow[t]{2}{*}{$13 \mathrm{H}-2,118-122$} & 109.08 & 0.60 & 0.6798 & - & - & $49 \mathrm{R}-2,123-125$ & 763.43 & 0.41 & 0.0823 & 13.2 & - \\
\hline & & & & & & $50 \mathrm{R}-5,125-130$ & 777.65 & 0.46 & 0.0746 & 13.9 & - \\
\hline \multirow[t]{2}{*}{ 131-808B- } & & & & & & $51 \mathrm{R}-1,0-3$ & 780.10 & 0.49 & 0.0795 & 14.6 & - \\
\hline & & & & & & $52 \mathrm{R}-2,0-2$ & 791.30 & 0.43 & 0.0698 & 13.4 & - \\
\hline $4 X-1,0-3$ & 139.90 & 0.74 & 0.8384 & - & - & $53 \mathrm{R}-1,141-142$ & 800.81 & 0.37 & 0.0062 & 10.2 & -23.9 \\
\hline $5 X-2,0-3$ & 151.00 & 0.48 & 0.5438 & - & -24.8 & $54 \mathrm{R}-1,0-2$ & 809.10 & 0.54 & 0.0377 & 15.2 & - \\
\hline $7 X-3,0-2$ & 171.80 & 0.42 & 0.4759 & - & - & $55 \mathrm{R}-2,0-2$ & 820.20 & 0.62 & 0.0433 & 16.9 & - \\
\hline $9 X-3,0-2$ & 191.20 & 0.75 & 0.8497 & - & - & $56 \mathrm{R}-1,145-146$ & 829.85 & 0.38 & 0.0586 & 13.4 & - \\
\hline $10 \times-4,0-5$ & 201.90 & 0.83 & 0.9404 & - & - & $57 \mathrm{R}-1,0-2$ & 838.10 & 0.44 & 0.0688 & 14.9 & - \\
\hline $11 X-1,145-150$ & 208.25 & 0.86 & 0.9744 & - & -25.9 & $58 \mathrm{R}-4,0-1$ & 851.90 & 0.36 & 0.0685 & 13.3 & -24.0 \\
\hline $13 X-2,0-3$ & 227.30 & 0.75 & 0.8497 & - & - & $59 \mathrm{R}-2,115-158$ & 859.75 & 0.47 & 0.0894 & 16.1 & - \\
\hline $14 X-1,0-3$ & 235.10 & 0.84 & 1.7287 & - & - & $60 \mathrm{R}-3,0-3$ & 869.80 & 0.36 & 0.0376 & 13.0 & - \\
\hline $15 \mathrm{X}-\mathrm{CC}, 0-3$ & 245.40 & 0.26 & 0.5351 & - & - & $61 R-2,113-115$ & 879.13 & 0.39 & 0.0407 & 6.1 & - \\
\hline $16 \mathrm{X}-1,118-121$ & 255.38 & 0.65 & 1.3377 & - & -25.2 & $62 R-2,148-150$ & 889.08 & 0.38 & 0.0397 & 6.0 & - \\
\hline $17 \mathrm{X}-2,127-130$ & 266.17 & 0.81 & 1.6669 & - & - & $63 R-2,0-3$ & 898.30 & 0.33 & 0.0267 & 5.3 & - \\
\hline $19 X-2,147-150$ & 285.47 & 0.62 & 1.2759 & - & - & $64 \mathrm{R}-2,0-3$ & 907.00 & 0.37 & 0.0299 & 5.8 & - \\
\hline \multirow[t]{2}{*}{$20 \mathrm{X}-2,0-3$} & 289.40 & 0.66 & 1.3582 & - & - & $65 \mathrm{R}-1,143-145$ & 916.53 & 0.40 & 0.0324 & 6.2 & - \\
\hline & & & & & & $66 \mathrm{R}-1,0-2$ & 924.80 & 0.50 & 0.0404 & 7.3 & - \\
\hline \multirow[t]{2}{*}{$131-808 \mathrm{C}-$} & & & & & & $67 R-1,0-2$ & 934.50 & 0.34 & 0.0393 & 6.0 & - \\
\hline & & & & & & $68 \mathrm{R}-1,15-20$ & 944.35 & 0.32 & 0.0370 & 5.8 & - \\
\hline $1 \mathrm{R}-1,130-132$ & 299.80 & 0.75 & 1.5435 & 39.5 & -25.1 & $69 \mathrm{R}-5,65-67$ & 960.45 & 0.29 & 0.0335 & 5.4 & -23.9 \\
\hline $2 \mathrm{R}-1,64-66$ & 308.64 & 0.66 & 1.3582 & 36.5 & - & $70 \mathrm{R}-2,148-150$ & 966.38 & 0.26 & 0.0277 & 4.9 & - \\
\hline $3 \mathrm{R}-1,0-3$ & 317.60 & 0.66 & 1.3582 & 37.0 & - & $71 R-2,115-120$ & 975.75 & 0.35 & 0.0434 & 5.8 & - \\
\hline $4 \mathrm{R}-1,0-3$ & 327.20 & 0.61 & 1.2553 & 35.5 & - & $72 \mathrm{R}-2,0-2$ & 984.30 & 0.20 & 0.0076 & 3.6 & - \\
\hline 5R-CC, $0-3$ & 337.40 & 0.67 & 1.3788 & 38.4 & - & $73 R-2,0-2$ & 993.60 & 0.28 & 0.0106 & 4.6 & - \\
\hline $6 \mathrm{R}-1,0-3$ & 346.60 & 0.61 & 1.2553 & 36.4 & - & $74 \mathrm{R}-1,145-150$ & 1003.25 & 0.21 & 0.0246 & 4.1 & - \\
\hline $7 R-1,59-60$ & 356.79 & 0.56 & 1.1524 & 34.7 & -24.6 & $75 \mathrm{R}-2,0-2$ & 1012.80 & 0.22 & 0.0079 & 3.9 & - \\
\hline $8 \mathrm{R}-2,124-126$ & 368.64 & 0.65 & 1.3377 & 39.1 & - & $76 \mathrm{R}-3,0-2$ & 1023.50 & 0.26 & 0.0094 & 4.5 & - \\
\hline $9 \mathrm{R}-1,131-132$ & 376.91 & 0.65 & 1.3377 & 39.5 & - & $77 \mathrm{R}-1,148-150$ & 1031.38 & 0.25 & 0.0029 & 4.0 & - \\
\hline $10 \mathrm{R}-3,99-100$ & 389.19 & 0.60 & 1.2348 & 37.9 & - & $78 \mathrm{R}-1,114-115$ & 1040.24 & 0.20 & 0.0077 & 3.7 & - \\
\hline $11 \mathrm{R}-1,0-2$ & 394.80 & 0.74 & 1.5229 & 43.0 & -24.8 & $79 \mathrm{R}-1,0-2$ & 1048.30 & 0.21 & 0.0121 & 4.0 & - \\
\hline $12 \mathrm{R}-3,0-2$ & 407.60 & 0.57 & 1.1730 & 35.2 & - & $80 \mathrm{R}-3,0-2$ & 1060.80 & 0.22 & 0.0126 & 4.1 & - \\
\hline $13 R-2,133-135$ & 417.13 & 0.43 & 0.8849 & 28.2 & - & $81 R-2,88-90$ & 1069.48 & 0.27 & 0.0155 & 4.8 & -24.6 \\
\hline $14 \mathrm{R}-3,124-126$ & 428.24 & 0.60 & 1.2348 & 34.9 & - & $82 R-1,148-150$ & 1077.98 & 0.27 & 0.0142 & 4.8 & - \\
\hline $15 \mathrm{R}-1,133-136$ & 435.03 & 0.61 & 1.2553 & 34.4 & - & $84 \mathrm{R}-1,115-120$ & 1093.15 & 0.29 & 0.0413 & 5.7 & - \\
\hline $16 \mathrm{R}-5,59-60$ & 449.59 & 0.54 & 1.1113 & 30.9 & -24.2 & $85 \mathrm{R}-1,0-2$ & 1098.30 & 0.26 & 0.0371 & 5.3 & - \\
\hline $17 R-5,0-3$ & 458.70 & 0.61 & 1.2553 & 32.7 & - & $86 \mathrm{R}-1,0-2$ & 1108.00 & 0.29 & 0.0413 & 5.7 & - \\
\hline $18 \mathrm{R}-1,0-3$ & 462.40 & 0.67 & 1.3788 & 33.7 & - & $87 R-1,0-2$ & 1117.60 & 0.23 & 0.0328 & 4.9 & - \\
\hline $19 \mathrm{R}-2,149-150$ & 474.99 & 0.40 & 0.8232 & 22.6 & - & $88 \mathrm{R}-1,0-2$ & 1126.90 & 0.27 & 0.0385 & 5.5 & - \\
\hline $20 \mathrm{R}-4,132-135$ & 487.52 & 0.59 & 1.2142 & 28.8 & - & $89 \mathrm{R}-1,0-2$ & 1136.60 & 0.23 & 0.0328 & 4.9 & - \\
\hline $21 R-1,0-3$ & 491.30 & 0.65 & 1.3377 & 31.0 & - & $90 \mathrm{R}-1,0-2$ & 1146.30 & 0.25 & 0.0356 & 5.2 & - \\
\hline $22 \mathrm{R}-5,0-2$ & 507.00 & 0.65 & 1.3377 & 31.4 & -23.9 & $91 R-1,26-27$ & 1156.16 & 0.28 & 0.0399 & 5.7 & -24.6 \\
\hline $23 \mathrm{R}-2,0-2$ & 512.20 & 0.43 & 0.8849 & 22.4 & - & $92 \mathrm{R}-1,0-2$ & 1165.60 & 0.30 & 0.0428 & 6.0 & - \\
\hline $24 \mathrm{R}-2,148-150$ & 523.28 & 0.54 & 1.1113 & 26.6 & - & $93 \mathrm{R}-1,4-6$ & 1175.34 & 0.27 & 0.0150 & 5.5 & - \\
\hline $25 \mathrm{R}-1,148-150$ & 531.48 & 0.73 & 1.5023 & 31.5 & - & $94 \mathrm{R}-1,0-3$ & 1184.90 & 0.26 & 0.0144 & 5.3 & - \\
\hline $26 \mathrm{R}-3,123-125$ & 543.93 & 0.63 & 1.2965 & 28.7 & -24.0 & $95 \mathrm{R}-1,7-10$ & 1194.67 & 0.21 & 0.0116 & 4.6 & -24.7 \\
\hline $27 \mathrm{R}-5,122-124$ & 556.52 & 0.19 & 0.3910 & 12.4 & - & $96 \mathrm{R}-2,0-2$ & 1205.80 & 0.05 & 0.0047 & 1.7 & - \\
\hline $28 \mathrm{R}-1,148-150$ & 560.38 & 0.53 & 1.0907 & 24.3 & - & $97 \mathrm{R}-1,0-2$ & 1214.00 & 0.05 & 0.0047 & 1.7 & - \\
\hline $29 \mathrm{R}-4,0-1$ & 573.10 & 0.46 & 0.9467 & 22.2 & - & $98 \mathrm{R}-1,0-2$ & 1223.70 & 0.12 & 0.0010 & 2.7 & - \\
\hline $30 \mathrm{R}-4,0-2$ & 582.80 & 0.31 & 0.6380 & 15.9 & - & $99 \mathrm{R}-1,0-2$ & 1233.40 & 0.04 & 0.0003 & 1.3 & - \\
\hline $31 \mathrm{R}-1,148-150$ & 589.08 & 0.54 & 1.1113 & 23.7 & - & $100 \mathrm{R}-1,0-2$ & 1234.00 & 0.19 & 0.0016 & 3.8 & -24.8 \\
\hline $32 \mathrm{R}-3,0-3$ & 600.30 & 0.36 & 0.7409 & 16.7 & -24.4 & $101 \mathrm{R}-4,148-150$ & 1258.18 & 0.04 & 0.0003 & 1.3 & - \\
\hline $33 \mathrm{R}-1,0-3$ & 606.90 & 0.60 & 1.2348 & 16.8 & - & $102 \mathrm{R}-2,0-2$ & 1261.50 & 0.06 & 0.0005 & 1.7 & - \\
\hline $35 \mathrm{R}-5,0-3$ & 632.20 & 0.34 & 0.0661 & 10.1 & - & $103 R-2,0-2$ & 1270.90 & 0.12 & 0.0010 & 2.8 & - \\
\hline $36 \mathrm{R}-3,0-1$ & 638.90 & 0.50 & 0.0972 & 13.3 & - & $104 \mathrm{R}-1,0-2$ & 1280.40 & 0.18 & 0.0015 & 3.7 & - \\
\hline
\end{tabular}

to $0.8 \%$ with high amplitudes in the sediments of the axial trench (Fig. 2, Table 1). Due to the high sedimentation rates we observe a dramatic increase of the mass accumulation rates of organic carbon from 0.2 to $1.6 \mathrm{~g}$ carbon per $\mathrm{cm}^{2}$ per $1000 \mathrm{yr}$ in sediments of the outer marginal trench wedge and a significant decrease in the axial trench wedge and slope apron sediments (Fig. 2, Table 1). However, from the comparison between TOC and sedimentation rates (Fig. 3) it is apparent that despite the high sedimentation rates, TOC values of the turbidite sequence do not exceed those of the hemipelagic sediments of the upper Shikoku Basin. This can be attributed to a relative dilution of organic carbon through turbidite flows. Although terrestrial vitrinite and inertinite are still the dominant components, alginite becomes more abundant from the transition between Shikoku Basin sediments to younger sediments of the outer marginal trench wedge 


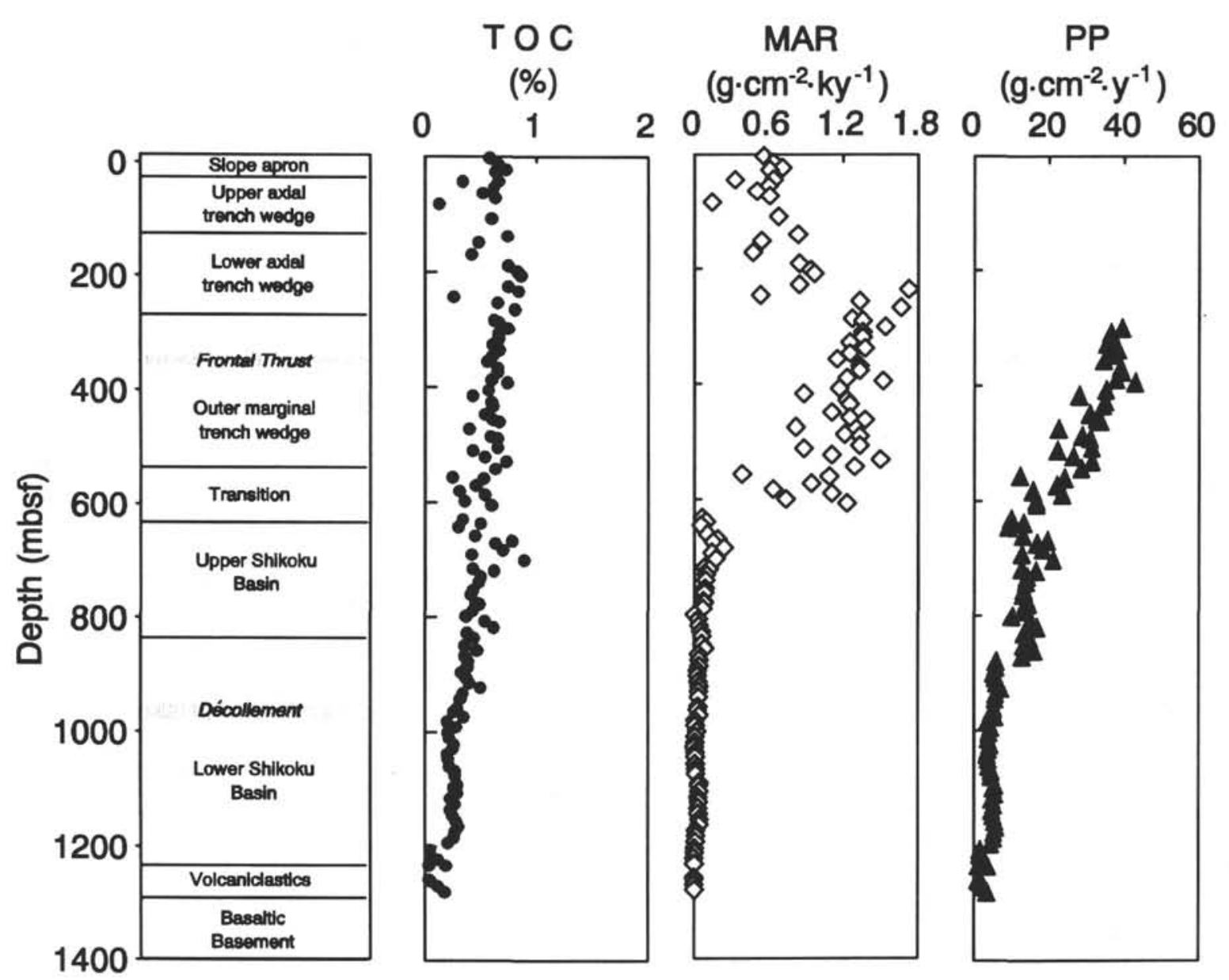

Figure 2. Sedimentary units, total organic carbon (TOC), organic mass accumulation rates (MAR), and estimated paleoproductivity (PP) at Site 808 .

(Fig. 4). This suggests a higher paleoproductivity (Fig. 2) closer to the shore related to a higher nutrient supply.

Isotope ratios of organic carbon decrease from average values of $-23.3 \%$ in upper Shikoku Basin sediments to $-24.5 \%$ in Nankai trench and wedge sediments (Fig. 4). These isotope values indicate a dominance of terrestrial organic matter in the younger sediments, which coincides with observations from optical studies (Fig. 4). As the isotopic composition of the bulk organic carbon is dominated by the terrigenous component, the carbon isotope shift indicates that the source of the terrestrial matter could have changed. This is supported by the observation that inertinite decreases from the basin-trenchtransition to the top of the sediments of the outer marginal trench wedge. Also, only one type of a low, mature vitrinite was found in these samples (Table 2, Fig. 5).

\section{Thermal Alteration of Organic Matter}

Thermal alteration of the organic matter in the sediments recovered from Site 808 is derived from vitrinite reflectance measurements. Two populations of allochthonous vitrinite are distinguished by reflectance measurements (Fig. 5). In both populations, reflectance increases with increasing depth and temperature. The reflectance of population 1 varies from $0.31 \%$ at $600 \mathrm{mbsf}$ to $0.68 \%$ at $1098 \mathrm{mbsf}$, whereas those of population 2 change from $0.59 \%$ to $0.99 \%$ in the same depth interval (Fig. 5). Between 1147 and 1234 mbsf reflectance values of vitrinite population 1 increase from $0.6 \%$ to $0.63 \%$, whereas vitrinite population 2 values show an increase from $0.9 \%$ to $0.97 \%$.
Based on the vertical distribution of reflectance values, it is likely that both types of vitrinite correspond to the temperature history at Site 808 , as we observe a parallel shift of reflectance with increasing depth and temperature. Vitrinites of population 1 correspond to more or less fresh terrestrial organic matter that is altered at Site 808 with increasing temperature. This implies that hydrocarbon generation at Site 808 should be largely related to changes of vitrinite 1 . The onset of significant thermal hydrocarbon formation should occur between 820 and $900 \mathrm{mbsf}$, where reflectance values of vitrinite 1 increase from $0.45 \%$ to $0.5 \%$. This coincides with the observation of Berner and Faber (this volume) on changes of gas concentrations. Ethane concentrations increase significantly below $800 \mathrm{mbsf}$. Furthermore, $n$-butane and $n$-pentane increase relative to isobutane and isopentane over the depth range of 750 to 900 mbsf, which can be taken as an indication of increasing temperature and maturity (Alexander et al., 1983).

Other maturity parameters as the illite/smectite ratio (Underwood et al., this volume) and the thermal alteration index (Firth, this volume) also show a correspondence with our coalification trend.

Vitrinites of population 2 may be interpreted as reworked macerals that already have undergone coalification before deposition in the Shikoku Basin. However, this assumption conflicts with physicalchemical models of thermal kerogen alteration (Waples, 1983, and literature cited therein; Burnham and Sweeney, 1989). Contrary to the observation on vitrinites of population 2, recycled organic matter should not be reactive until temperatures exceed those of the first alteration cycle; as for any further increment of maturation, recycled organic matter needs higher activation energies and hence higher 


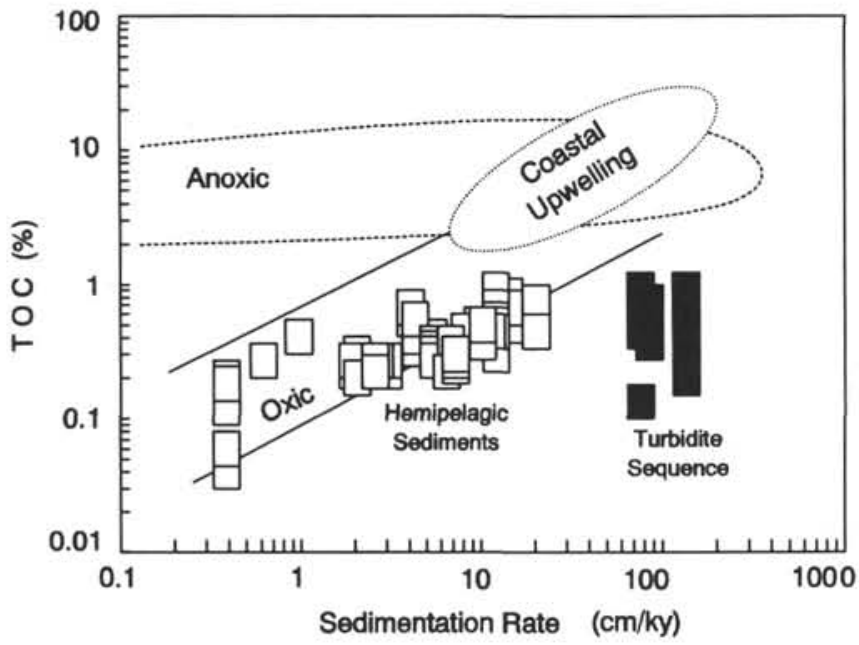

Figure 3. Comparison of total organic carbon and sedimentation rates of sediments recovered from Site 808 . Fields of classification have been adapted from Stein et al. (1988).

temperatures than have been reached during primary alteration. The problem of two populations of vitrinite corresponding to depth and temperature at Site 808 cannot presently be solved.

\section{CONCLUSIONS}

Microscopic studies reveal a predominance of terrestrial organic matter in sediments of Site 808. Terrestrial vitrinite and inertinite are more abundant ( $73 \%$ to $100 \%$ ) than marine organic matter (alginite, $0 \%$ to $27 \%$ ) which increases from open oceanic deposits of the Shikoku Basin sediments to sediments of the outer trench wedge. The abundance of terrestrial organic matter is also reflected through carbon isotope values of $-23 \%$ to $-25.9 \%$.

Mass accumulation rates of organic carbon are low in hemipelagic sediments of the Shikoku Basin $\left(<0.2 \mathrm{~g} / \mathrm{cm}^{2} / \mathrm{k}\right.$.y. $)$ but increase significantly in sediments of the Nankai Trench $\left(0.2\right.$ to $1.7 \mathrm{~g} / \mathrm{cm}^{2} / \mathrm{k} . \mathrm{y}$.). Although the organic mass accumulation is high in sediments of the Nankai Trench, a comparison of sedimentation rates and total organic carbon suggests relative dilution of organic carbon through turbidite flows. Calculated marine paleoproductivity of organic carbon is low in sediments of the open ocean (Shikoku Basin) and increases closer to the shore (Nankai Trench). Thermal evolution of organic matter is obtained from vitrinite reflectance measurements. Two populations of vitrinites have been observed between 600 and 1234 mbsf. Reflectance values change with increasing depth and temperature in both groups of vitrinite $(0.3 \%$ to $0.68 \%$ in group $1 ; 0.6 \%$ to $1 \%$ in group 2 ).

\section{ACKNOWLEDGMENTS}

The work of U. Berner was generously supported by grants of the German Research Foundation and the German Ministry of Research and Technology. We also thank J.R. Castano for critically reviewing this paper.

\section{REFERENCES*}

Alexander, R., Kagi, R.I., and Woodhouse, G.W., 1983. Variation in ratio of isomeric butanes with sediment temperature in Carnarvon Basin of Western Australia. In Bjoroy, M. (Ed.), Advances in Organic Geochemistry 1981: New York (Wiley), 76-79.

Bordovskiy, O.K., 1965. Accumulation of organic matter in bottom sediments. Mar. Geol., 3:33-82.

Burnham, A.K., and Sweeney, J.J., 1989. A chemical kinetic model of vitrinite maturation and reflectance. Geochem. Cosmochim. Acta, 53:2649-2657.

Hedges, J.I., and Mann, D.C., 1979. The lignin geochemistry of marine sediments from the southern Washington coast. Geochim. Cosmochim. Acta, 43:1809-1818.

Müller, P.J., and Suess, E., 1979. Productivity, sedimentation rate, and sedimentary organic matter in the oceans. I. Organic carbon preservation. Deep-Sea Res. Part A, 26:1347-1362.

Prahl, F.G., 1985. Chemical evidence of differential particle dispersal in the southern Washington coastal environment. Geochim. Cosmochim. Acta, 49:2533-2539.

Prahl, F.G., and Muehlhausen, L.A., 1989. Lipid biomarkers as geochemical tools for paleoceanographic study. In Berger, W.H., Smetaceck, V., and Wefer, G. (Eds.), Productivity of the Ocean: Present and Past. Dahlem Workshop, Life Sci. Res. Rep., 44:271-289.

Romankevich, E.A., 1984. Geochemistry of Organic Matter in the Ocean: New York (Springer-Verlag).

Sackett, W.M., Eckelmann, W.R., Bender, M.L., and Bé, A.W.H., 1966. Über die Isotopenzusammensetzung von organischem Kohlenstoff aus Meeresplankton und seine Beziehung zu marinen Sedimenten. Erdoel und Kohle, 19:562-564.

Schoell, M., 1984. Wasserstoff- und Kohlenstoffisotope in organischen Substanzen, Erdölen und Erdgasen. Geol. Jahrb., Reihe D, 67.

Stein, R., 1986. Surface-water paleo-productivity as inferred from sediments deposited in oxic and anoxic deep-water environments of the Mesozoic Atlantic Ocean. In Degens, E.T., et al. (Eds.), Mitt. Geol.-Palaeontol. Inst. Univ. Hamburg, 60:55-70.

Stein, R., ten Haven, H.L., Littke, R., Rullkötter, J., and Welte, D.H., 1989. Accumulation of marine and terrigenous organic carbon at upwelling Site 658 and nonupwelling Sites 657 and 659: implications for the reconstruction of paleoenvironments in the eastern subtropical Atlantic through late Cenozoic times. In Ruddiman, W., Sarnthein, M., et al., Proc. ODP, Sci. Results, 108: College Station, TX (Ocean Drilling Program), 361-385.

Taira, A., Hill, I., Firth, J.V., et al., 1991. Proc. ODP, Init. Repts., 131: College Station, TX (Ocean Drilling Program).

Tissot, B.P., and Welte, D.H., 1984. Petroleum Formation and Occurrence (2nd ed.): Heidelberg (Springer-Verlag).

Waples, D.W., 1983. Physical-chemical models for oil generation. Color. School of Mines Q., 78:15-30.

Zafiriou, O.C., Gagosian, R.B., Peltzer, E.T., Alford, J.B., and Loder, T., 1985. Air-to-sea fluxes at Enewetak Atoll. J. Geophys. Res., 90:2409-2433.

\footnotetext{
* Abbreviations for names of organizations and publication titles in ODP reference lists follow the style given in Chemical Abstracts Service Source Index (published by American Chemical Society).
}

Date of initial receipt: 3 February 1992

Date of acceptance: 6 October 1992

Ms 131SR-132 

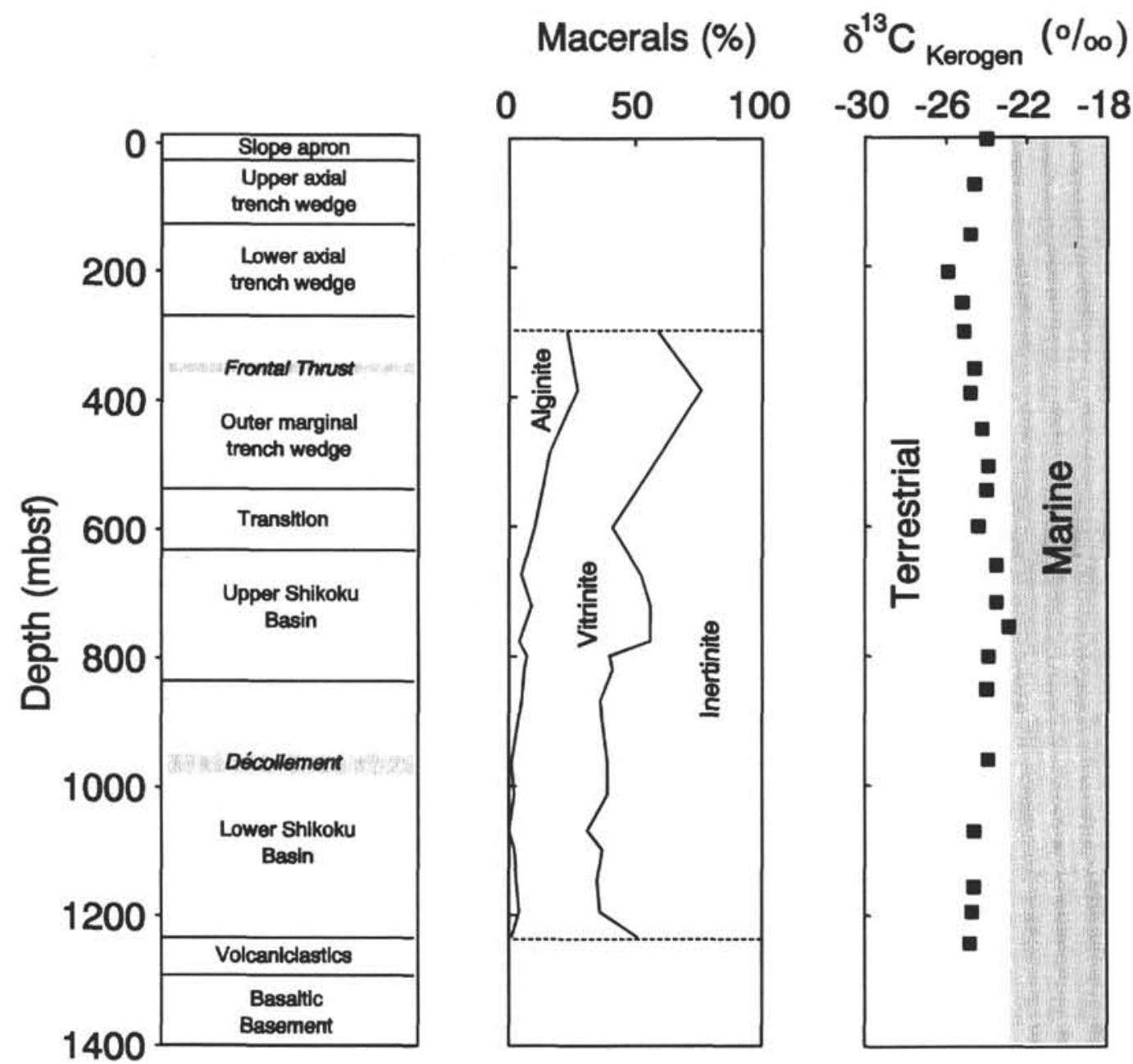

Figure 4. Maceral composition and carbon isotope ratios of kerogens at Site 808.

Table 2. Total organic carbon, maceral composition, and vitrinite reflectance of two vitrinite populations in sediments of Site 808 .

\begin{tabular}{|c|c|c|c|c|c|c|c|}
\hline $\begin{array}{l}\text { Core, section, } \\
\text { interval }(\mathrm{cm})\end{array}$ & $\begin{array}{l}\text { Depth } \\
\text { (mbsf) }\end{array}$ & $\begin{array}{l}\text { TOC } \\
(\%)\end{array}$ & $\begin{array}{l}\mathrm{Ro}_{1} \\
(\%)\end{array}$ & $\begin{array}{l}\mathrm{Ro}_{2} \\
(\%)\end{array}$ & $\begin{array}{l}\text { Vitrinite } \\
(\%)\end{array}$ & $\begin{array}{l}\text { Alginite } \\
(\%)\end{array}$ & $\begin{array}{c}\text { Inertinite } \\
(\%)\end{array}$ \\
\hline \multicolumn{8}{|l|}{$131-808 \mathrm{C}-$} \\
\hline IR-1, 7-8 & 298.57 & 0.60 & 0.32 & - & 36.0 & 23.0 & 41.0 \\
\hline $10 \mathrm{R}-3,26-28$ & 388.46 & 0.62 & 0.33 & - & 49.0 & 27.0 & 24.0 \\
\hline $20 \mathrm{R}-4,8-9$ & 486.28 & 0.59 & 0.32 & - & 44.0 & 16.0 & 40.0 \\
\hline $32 \mathrm{R}-3,12-13$ & 600.42 & 0.36 & 0.31 & 0.59 & 31.0 & 10.0 & 59.0 \\
\hline $40 \mathrm{R}-1,25-26$ & 674.45 & 0.63 & 0.36 & 0.64 & 47.5 & 5.0 & 47.5 \\
\hline $45 \mathrm{R}-1,15-17$ & 722.15 & 0.62 & 0.38 & 0.62 & 47.0 & 9.0 & 44.0 \\
\hline 50R-5, 16-17 & 776.56 & 0.50 & 0.35 & 0.68 & 52.0 & 4.0 & 44.0 \\
\hline $53 \mathrm{R}-1,8-10$ & 799.48 & 0.40 & 0.39 & 0.67 & 33.0 & 7.0 & 60.0 \\
\hline $55 \mathrm{R}-2,11-12$ & 820.31 & 0.62 & 0.45 & 0.68 & 35.0 & 6.0 & 59.0 \\
\hline $60 \mathrm{R}-3,5-6$ & 869.85 & 0.36 & 0.42 & 0.68 & 31.0 & 5.0 & 64.0 \\
\hline $70 \mathrm{R}-2.7-8$ & 964.97 & 0.30 & 0.50 & 0.71 & 38.0 & 1.0 & 61.0 \\
\hline $75 R-2,23-24$ & 1013.03 & 0.22 & 0.61 & 0.87 & 37.0 & 2.0 & 61.0 \\
\hline $81 R-2,14-16$ & 1068.74 & 0.27 & 0.59 & 0.86 & 31.0 & 0.0 & 69.0 \\
\hline $85 \mathrm{R}-1,9-11$ & 1098.39 & 0.26 & 0.68 & 0.99 & 35.0 & 2.0 & 63.0 \\
\hline $90 \mathrm{R}-1,60-61$ & 1146.90 & 0.25 & 0.60 & 0.91 & 32.0 & 3.0 & 65.0 \\
\hline 95R-1, 22-23 & 1194.82 & 0.21 & 0.61 & 0.90 & 32.0 & 4.0 & 64.0 \\
\hline $100 \mathrm{R}-1,36-37$ & 1234.36 & 0.04 & 0.63 & 0.97 & 50.0 & 1.0 & 49.0 \\
\hline
\end{tabular}

Note: A minor amount of cutinite was observed in Sample 131-808C-10R-3, 26-28 cm. 


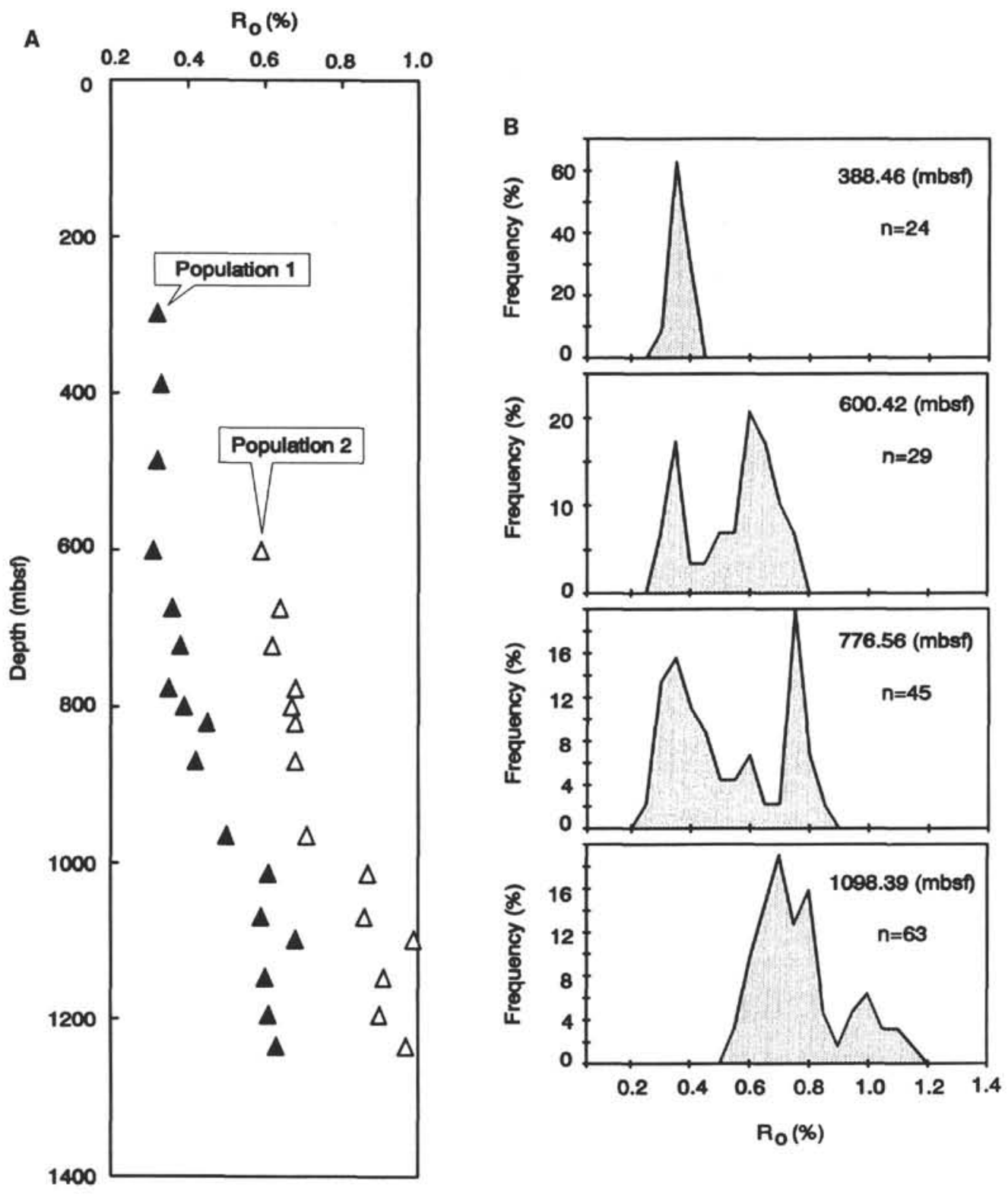

Figure 5. A. Vertical variation of vitrinite reflectance values of two vitrinite populations at Site 808. B. Examples of frequency distributions of vitrinite reflectance values in selected samples. Two major populations can be distinguished below $600 \mathrm{mbsf}$. Vitrinites of population 2 are likely reworked organic material. 